Gut, 1978, 19, 315-320

\title{
Inhibition by somatostatin (growth-hormone release-inhibiting hormone, GH-RIH) of gastric acid and pepsin and $\mathrm{G}$-cell release of gastrin
}

\author{
A. A. J. BARROS D'SA, ${ }^{1}$ S. R. BLOOM, AND J. H. BARON² \\ From the Departments of Surgery and Medicine, Royal Postgraduate Medical School, London
}

SUMMARY Somatostatin (cyclic growth-hormone release-inhibiting hormone-GH-RIH) was infused into dogs with gastric fistulae. Somatostatin inhibited gastric acid response to four gastric stimulants-insulin, food, histamine, and pentagastrin. Histamine- and pentagastrin-stimulated pepsins were inhibited similarly to inhibition of acid. Somatostatin inhibited the gastrin response to insulin and food.

The cyclic hypothalamic tetradecapeptide, growthhormone release-inhibiting hormone (GH-RIH), somatostatin, inhibits the secretion of growth hormone (Brazeau et al., 1973) and TSH (Hall et al., 1973) from the anterior pituitary, as well as insulin (Alberti et al., 1973) and glucagon (Mortimer et al., 1974) from the pancreas. More recently, somatostatin has been found markedly to suppress the release of gastrin in normal subjects (Bloom et al., 1974) and patients with the Zollinger-Ellison syndrome (Bloom et al., 1974, 1975). The first nonendocrine effects of somatostatin to be demonstrated were direct inhibition of gastric acid secretion in dogs (Barros D'Sa et al., 1975a) and of acid and pepsin in cats (Gomez-Pan et al., 1975). Similar inhibition by somatostatin of gastric acid and pepsin has been found in response to betazole in man (Lankisch et al., 1975), pentagastrin in man (Arnold and Creutzfeldt, 1975), and dog (Konturek et al., 1976) and in response to histamine, peptone, and urecholine in dogs (Konturek et al., 1976). Recent morphological studies have demonstrated somatostatin in the islet cells of the pancreas (Luft et al., 1974) and localised in the D cells of the pancreas, the stomach, and the duodenum (Polak et al., 1975).

In view of reported effects of somatostatin such as thrombocytopenia (Ricketts, 1975), impaired platelet aggregation (Besser et al., 1975; Goodner, 1975), with increased concentrations of the fibrin degradation product FgE in man (Lancet, 1975), we decided

\footnotetext{
${ }^{1}$ Present address: Singleton Hospital, Swansea.

${ }^{2}$ Address for correspondence: Dr J. H. Baron, Department of Surgery, Royal Postgraduate Medical School, Hammersmith Hospital, London, W12 0HS.

Received for publication 14 November 1977
}

to perform further studies in dogs rather than in man. These experiments were designed to test the effects of somatostatin on gastric acid, gastrin and pepsin in response to insulin hypoglycaemia, a meat meal, histamine, and pentagastrin.

\section{Methods}

Four trained dogs $(25-30 \mathrm{~kg})$ with previously fashioned gastric fistulae were studied after an overnight fast. Blood samples were drawn from a venous catheter and $0.9 \%$ saline or somatostatin infusion given into a superficial leg vein. Pure synthetic cyclic somatostatin was used (Baychem Ltd) and was infused in $0.9 \%$ saline in concentrations in the range $0 \cdot 5-32 \mu \mathrm{g} / \mathrm{kg} \cdot \mathrm{h}$.

During histamine and pentagastrin-stimulated experiments somatostatin was infused in the second hour of a three hour infusion of submaximal doses of histamine acid phosphate $(0.5 \mu \mathrm{g} / \mathrm{kg} \cdot \mathrm{min})$ and pentagastrin $(1 \mu \mathrm{g} / \mathrm{kg} \cdot \mathrm{h})$. In the insulin experiments insulin $0.2 \mathrm{u} / \mathrm{kg}$ was given as a single intravenous injection, and somatostatin ( 5 or $8 \mu \mathrm{g} / \mathrm{kg} \cdot \mathrm{h}$ ) infused for 30 minutes before and 90-120 minutes after the insulin injection. Fifteen minute collections of gastric juice were made and the volume and titratable acidity (to pH 7) were measured. Pepsin concentration was measured by an Autoanalyzer method (Vatier et al., 1968) using haemoglobin as a substrate (Anson and Mirsky, 1932). Blood samples were also taken every 15 minutes for measurements of plasma glucose and gastrin. Glucose was measured by the glucose oxidase method of Wincey and Marks (1961) adapted for an Autoanalyzer. Plasma immunoreactive gastrin was measured by radioimmunoassay 
(Russell et al., 1976) using antiserum Gas 8 which is sensitive to changes in human G-17 of $1.5 \mathrm{pmol} / \mathrm{l}$, reacts $50 \%$ with G34, but has no affinity for pentagastrin or big big gastrin.

During meal-stimulated experiments somatostatin was given intravenously in the first two hours of a three hour experiment and acid output was measured by the technique of intragastric titration with sodium bicarbonate (Fordtran and Walsh, 1973) modified for the dog (Barros D'Sa et al., 1975b). The meal consisted of Lassie meat $(20 \mathrm{~g} / \mathrm{kg})$. Plasma gastrins were also measured.

Results (Table)

INSULIN

Dogs 1 and 2 were infused with $8 \mu \mathrm{g} / \mathrm{kg} \cdot \mathrm{h}$ somatostatin (Fig. 1) and dogs 3 and 4 with $5 \mu \mathrm{g} / \mathrm{kg} \cdot \mathrm{h}$ (Fig. 2). The mean degree of hypoglycaemia after insulin during the control infusion of saline was not significantly different from that seen after insulin during somatostatin infusion and there was no observable difference in the behaviour of the dogs on the two occasions. The mean gastrin increment was inhibited by $70 \%$ after the lower dose and $86 \%$ after the higher dose of somatostatin, almost identical with the inhibition of insulin-stimulated acid output of $74 \%$ and $85 \%$ after these doses.

MEAL (Fig. 3)

Inhibition of acid output was greater with increasing doses of somatostatin. With the lowest dose of $0.5 \mu \mathrm{g} / \mathrm{kg} \cdot \mathrm{h}$ there was a rebound in secretion after the somatostatin infusion was stopped, with the acid output exceeding control levels. During the two-hour infusion with higher doses of $1 \mu \mathrm{g} / \mathrm{kg} \cdot \mathrm{h}$, gastric acid was totally inhibited in every dog with some return of secretion after stopping the infusion. Acid secre-

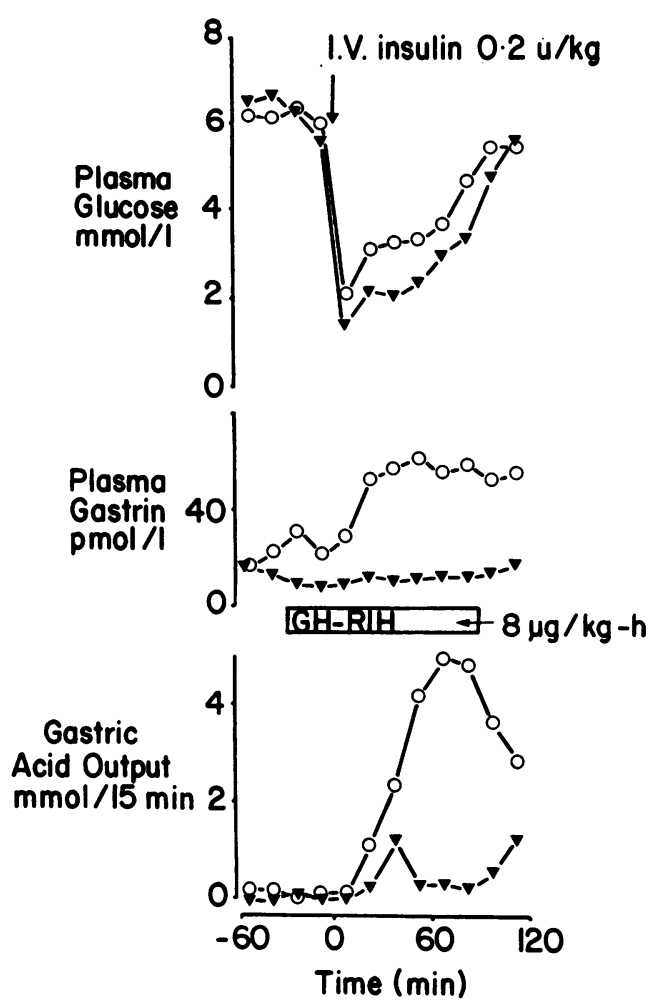

Fig. 1 Inhibition by somatostatin $(G H-R I H) \& \mu g / k g-h$ of insulin-stimulated gastric acid and plasma gastrin. In this and subsequent graphs $\bigcirc-\bigcirc$ indicates the mean results in control experiments and $\nabla-\nabla$ with $G H-R I H$ $8 \mu g / k g-h$.

tion was completely inhibited throughout the three hours with the other four doses, 2, 4, 8 and 16 $\mu \mathrm{g} / \mathrm{kg} \cdot \mathrm{h}$. The inhibition by somatostatin of mealstimulated gastrin was also dose dependent (Fig. 4).

Table Percentage inhibition of acid, pepsin, and gastrin by somatostatin

\begin{tabular}{|c|c|c|c|c|c|c|c|}
\hline \multirow[b]{2}{*}{ Stimulant } & \multicolumn{7}{|c|}{ Mean percentage inhibition after somatostatin (dose $\mu \mathrm{g} / \mathrm{kg}-\mathrm{h}$ ) } \\
\hline & 0.5 & 1 & 2 & 4 & 8 & 16 & 32 \\
\hline Insulin & & & & $74^{2}$ & $85^{2}$ & & \\
\hline Meal & $71^{8}$ & $100^{8}$ & $100^{8}$ & $100^{8}$ & $100^{8}$ & $100^{8}$ & \\
\hline Histamine & & & & & $42^{4}$ & 634 & $82^{4}$ \\
\hline Pentagastrin & & & & & & 944 & \\
\hline Histamine & & & & & $72^{4}$ & $57^{4}$ & $74^{4}$ \\
\hline Pentagastrin & & & & & & $76^{4}$ & \\
\hline \multicolumn{8}{|l|}{ Gastrin rise } \\
\hline Insulin & & & & $70^{2}$ & $86^{2}$ & & \\
\hline Meal & $0^{8}$ & $50^{8}$ & $75^{8}$ & $85^{8}$ & $95^{8}$ & $75^{8}$ & \\
\hline
\end{tabular}

Comparisons have been made for histamine and pentagastrin between the $\mathbf{3 0}$ minutes before somatostatin compared with the second half hour of the somatostatin infusion, for meals between the fourth half hour of somatostatin and control, and after insulin between the 90 minutes of somatostatin infusion and control. The superscripts indicate the number of experiments. The mean percentage inhibition by somatostatin $4 \mu \mathrm{g} / \mathrm{kg}-\mathrm{h}$ represents the pooled results from doses of 4 and $5 \mu \mathrm{g} / \mathrm{kg}-\mathrm{h}$. 


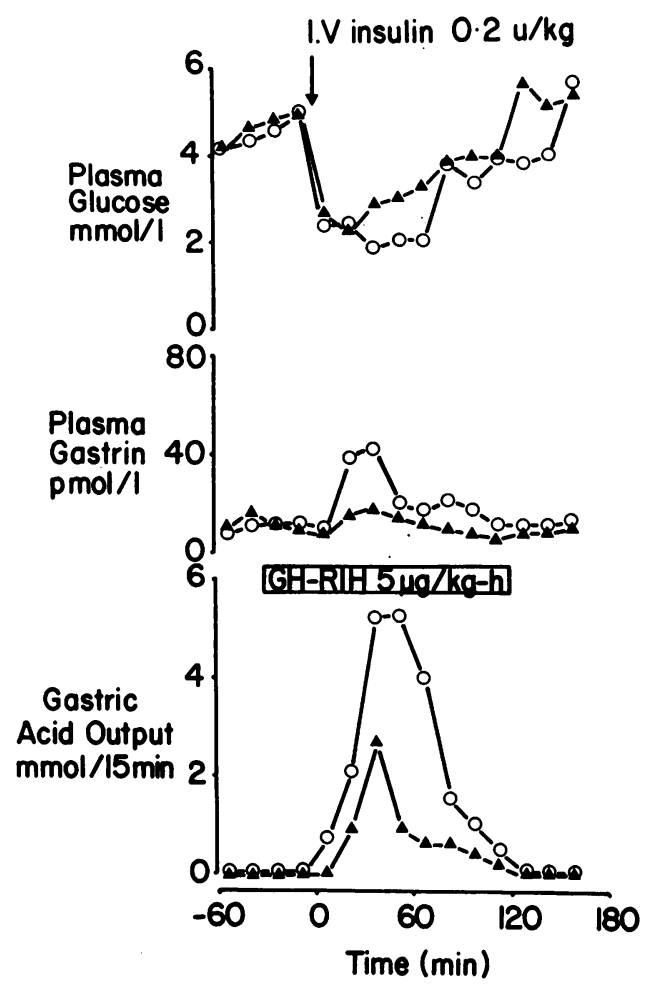

Fig. 2 Inhibition by $G H-R I H 5 \mu g / k g-h(\Delta-\Lambda)$ of insulin-stimulated gastric acid and plasma gastrin.

In all experiments except when the lowest dose of somatostatin was used there was a marked depression in plasma gastrin levels with a definite rise after the somatostatin infusion was stopped. The recovery phase of gastrin after stopping somatostatin was also dose dependent, with the least recovery with higher doses of somatostatin.

Pepsin data are difficult to interpret because of the initial washout rise of pepsin after histamine followed by a fall and rise. Pepsin outputs after somatostatin were inhibited less than acid outputs (Table).

\section{HIST AMINE}

Acid output was depressed by somatostatin in histamine experiments (Fig. 5).

\section{PENTAGASTRIN}

Pentagastrin-stimulated acid output decreased immediately and rapidly after somatostatin was infused (Fig. 6). Acid output was reduced by $94 \%$ and pepsin output reduced by $76 \%$. There was some recovery in acid output and marked recovery in pepsin output after the somatostatin infusion was stopped.

\section{Basal plasma gastrin}

This was not affected by the infusions of histamine or pentagastrin. During the somatostatin infusion these still basal plasma levels were depressed with some recovery after the somatostatin infusions were stopped (Figs. 5 and 6).

\section{Discussion}

In these experiments somatostatin inhibited the secretion of tive parietal cells in response to insulin,

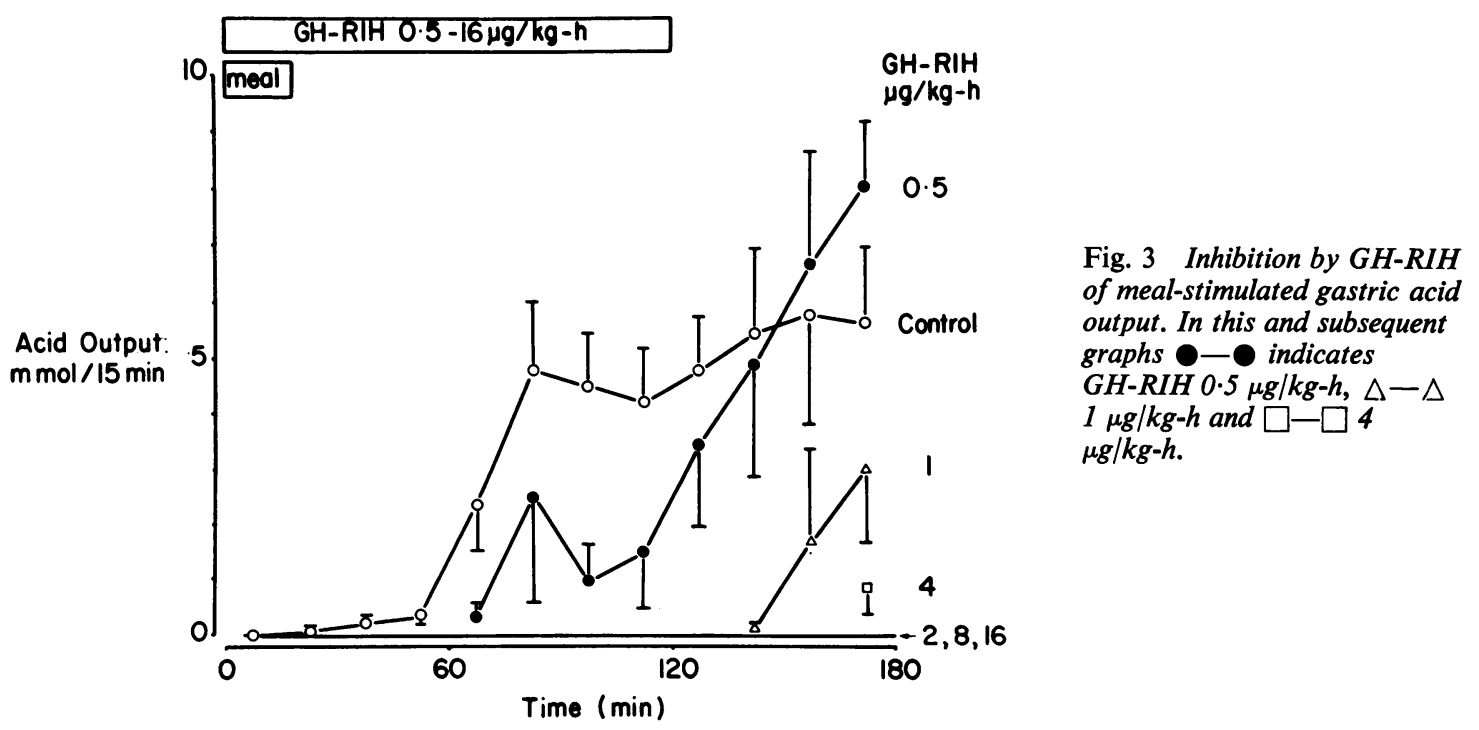




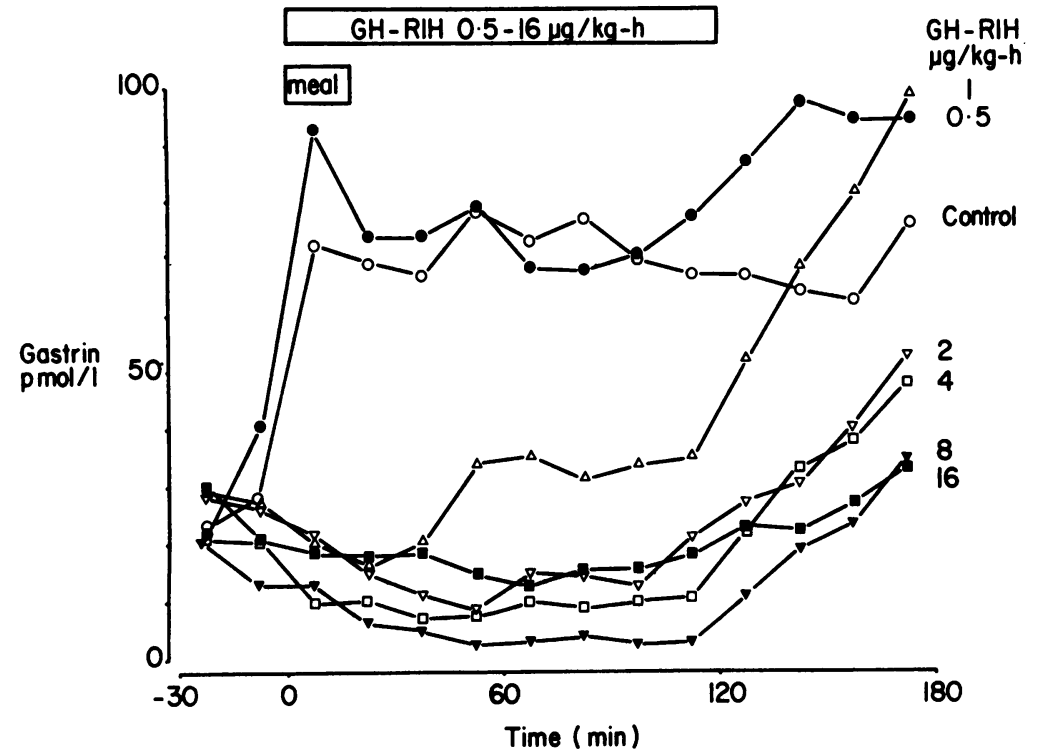

Fig. 4 Inhibition by $\mathrm{GH}-\mathrm{RIH}$ of meal-stimulated plasma gastrin. In this and subsequent graphs $\nabla-\nabla$ indicates $G H-R I H 2 \mu g / k g-h$ and $\square-\square 16 \mu g / k g-h$.

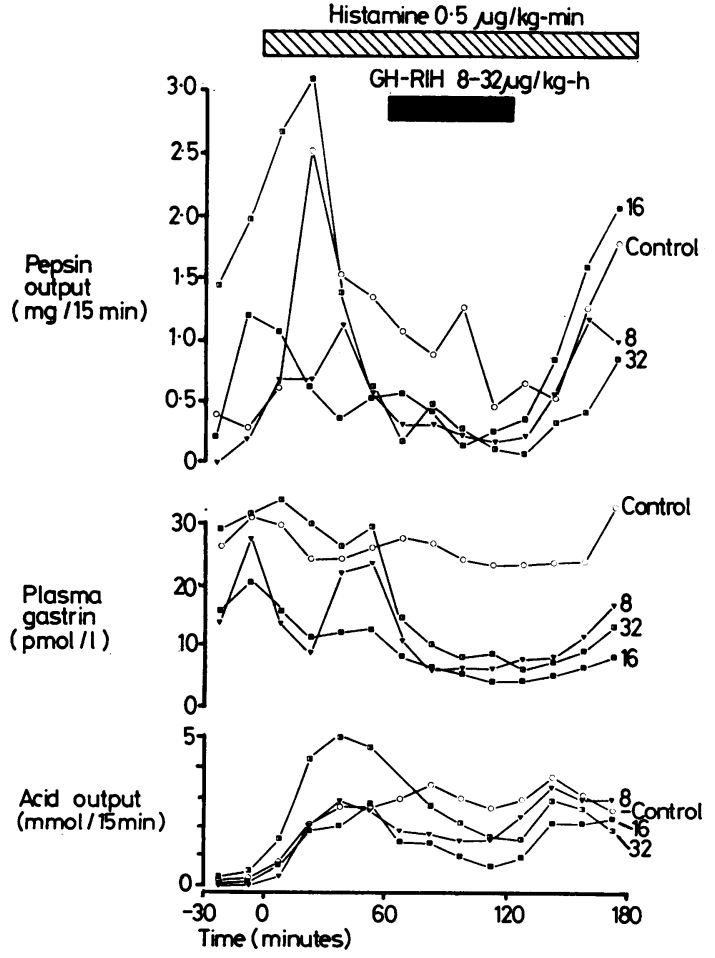

Fig. 5 Inhibition by $\mathrm{GH}-\mathrm{RIH}$ of histamine-stimulated plasma gastrin and gastric acid and pepsin output. $\square-\square$ indicates $\mathrm{GH}-\mathrm{RIH} 32 \mu \mathrm{g} / \mathrm{kg}-\mathrm{h}$.

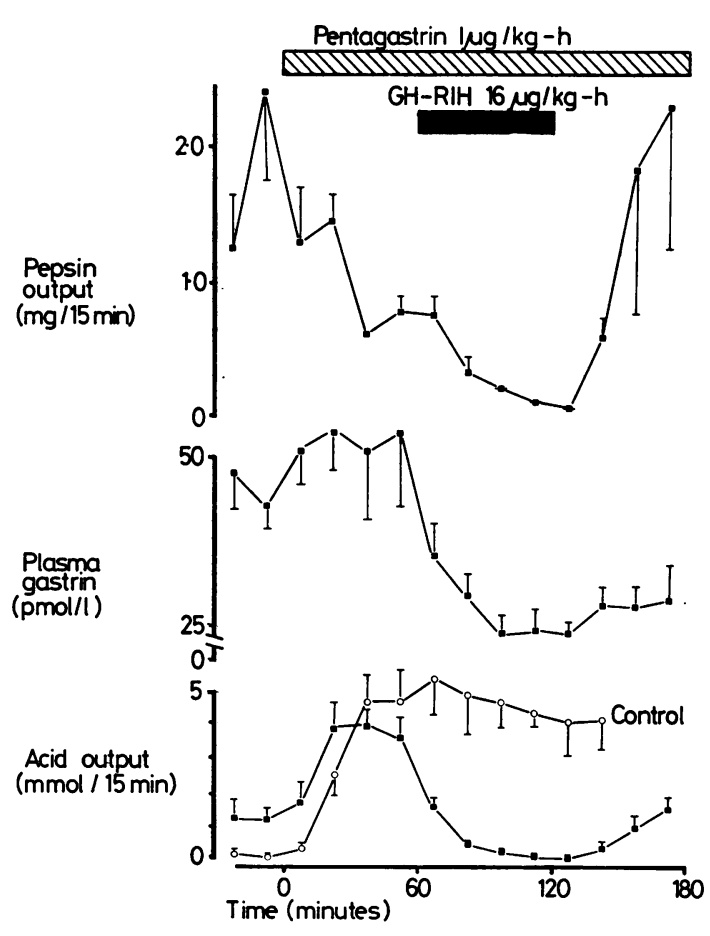

Fig. 6 Inhibition by $G H-R I H, 16 \mu g / k g-h$, of pentagastrin-stimulated plasma gastrin and gastric acid and pepsin output. 
meals, histamine, and pentagastrin, and inhibited the release of gastrin from the G-cells both under basal conditions and in response to insulin and to a meal. In the insulin studies a comparable degree of hypoglycaemic stimulus was attained in the control and test experiments, so that somatostatin's inhibition of insulin-stimulated gastric secretion must have been due to inhibition of the release of gastrin from G-cells, and/or an effect on the parietal cells to gastrin and/or direct vagal cholinergic stimuli.

The present studies have established in dogs that somatostatin inhibits gastrin release in response both to vagal stimulation and food as in normal man after a meal (Bloom et al., 1974), and in hypergastrinaemic patients with pernicious anaemia and a gastrinoma (Bloom et al., 1974).

The relationship of gastrin release to gastric acid secretion after hypoglycaemia is complex (Cowley et al., 1973). In man the peak plasma gastrin after insulin hypoglycaemia precedes the peak acid output by 15 to 30 minutes (Cowley et al., 1973) and a similar delay was seen in dogs (Figs. 1 and 2), suggesting that the vagally released gastrin could indirectly prime the parietal cells to respond to direct cholinergic vagal stimulation.

In the meal experiments there was a tendency for gastric acid and plasma gastrin to rebound after the infusions of low doses of somatostatin were stopped. In the histamine, insulin, and pentagastrin experiments there was some recovery in acid output after the inhibitory influence of somatostatin was removed but there was no rebound (Gomez-Pan et al., 1975), nor has a rebound rise been seen in the hormone secretion of patients with hormone secreting tumours after stopping somatostatin (Mortimer et al., 1974; Bloom et al., 1974).

Histamine- and pentagastrin-stimulated pepsin was inhibited by somatostatin to a similar degree as inhibition of acid. Inhibition by somatostatin of acid and pepsin secretion in response to histamine stimulation was less marked than its effect on pentagastrin-stimulated acid and pepsin secretion.

Somatostatin inhibits the release of acid, pepsin, and gastrin from parietal, chief, and G-cells in response to a meal, of acid and gastrin in response to insulin, and of acid and pepsin in response to pentagastrin and histamine. The physiological significance of this inhibition remains uncertain. Somatostatin has not been detected in peripheral blood, so that it is unlikely to be a circulating hormone. However, the wide distribution of somatostatin in the alimentary system could allow it a paracrine role as a local chemical regulator of exocrine as well as endocrine secretion.
The support of Pfizer (U.K.) and the Wellcome Trust is gratefully acknowledged.

\section{References}

Alberti, K. G. M. M., Christensen, N. J., Christensen, S. E., Prange Hansen, Aa., Iversen, J., Lundbæk, K., SeyerHansen, K., and Ørskov, H. (1973). Inhibition of insulin secretion by somatostatin. Lancet, 2, 1299-1301.

Anson, M. L., and Mirsky, A. E. (1932). The estimation of pepsin with haemoglobin. Journal of General Physiology, 16, 59-63.

Arnold, R., and Creutzfeldt, W. (1975). Hemmung der pentagastrininduzierten Săuresekretion des Magens beim Menschen durch Somatostatin. Deutsche Medizinische Wochenschrift, 100, 1014-1016.

Barros D'Sa, A. A. J., Bloom, S. R., and Baron, J. H. (1975a). Direct inhibition of gastric acid by growthhormone release-inhibiting hormone in dogs. Lancet, 1 , 886-887.

Barros D'Sa, A. A. J., Spencer, J., and Baron, J. H. (1975b). An assessment of intragastric titration of acid secretion in man, dog and artificial stomach. Clinical Science and Molecular Medicine, 49, 25-26P.

Besser, G. M., Paxton, A. M., Johnson, S. A. N., Moody, E. J., Mortimer, C. H., Hall, R., Gomez-Pan, A., Schally, A. V., Kastin, A. J., and Coy, D. H. (1975). Impairment of platelet function by growth-hormone release-inhibiting hormone. Lancet, 1, 1166-1168.

Bloom, S. R., Mortimer, C. H., Thorner, M. O., Besser, G. M., Hall, R., Gomez-Pan, A., Roy, V. M., Russell R. C. G., Coy, D. H., Kastin, A. J., and Schally, A. V. (1974). Inhibition of gastrin and gastric-acid secretion by growth-hormone release-inhibiting hormone. Lancet, 2, 1106-1109.

Bloom, S. R., Russell, R. C. G., Barros D'Sa, A. A. J., Baron, J. H., Besser, G. M., Hall, R., Coy, D. H., Kastin, A. J., and Schally, A. V. (1975). Inhibition of gastrin and gastric acid by growth-hormone release-inhibiting hormone (Abstract). Gut, 16, 396.

Brazeau, P., Vale, W., Burgus, R., Ling, N., Butcher, M., Rivier, J., and Guillemin, R. (1973). Hypothalamic polypeptide that inhibits the secretion of immunoreactive pituitary growth hormone. Science, 179, 77-79.

Cowley, D. J., Baron, J. H., Hansky, J., and Korman, M. G. (1973). The effect of insulin hypoglycaemia on serum gastrin and gastric acid in normal subjects and patients with duodenal ulcer. British Journal of Surgery, 60, 438-443

Fordtran, J. S., and Walsh, J. H. (1973). Gastric acid secretion rate and buffer content of the stomach after eating. Results in normal subjects and in patients with duodenal ulcer. Journal of Clinical Investigation, 52, 645-657.

Gomez-Pan, A., Reed, J. D., Albinus, M., Shaw, B., Hall, R., Besser, G. M., Coy, D. H., Kastin, A. J., and Schally, A. V. (1975). Direct inhibition of gastric acid and pepsin secretion by growth-hormone release-inhibiting hormone in cats. Lancet, $1,888-890$.

Goodner, C. J. (1975). Somatostatin leads to glucagon's renaissance. New England Journal of Medicine, 292, 1022-1023.

Hall, R., Besser, G. M., Schally, A. V., Coy, D. H., Evered, D., Goldie, D. J., Kastin, A. J., McNeilly, A. S., Mortimer, C. H., Phenekos, C., Tunbridge, W. M. G., and Weightman, D. (1973). Action of growth-hormone-releaseinhibitory hormone in healthy men and in acromegaly. Lancet, 2, 581-584.

Konturek, S. J., Tasler, J., Cieszkowski, M., Coy, D. H., and Schally, A. V. (1976). Effect of growth-hormone releaseinhibiting hormone on gastric secretion, mucosal blood 
flow, and serum gastrin. Gastroenterology, 70, 737-741.

Lancet (1975). Somatostatin and diabetes. Leading article. Lancet, 1, 1323-1324.

Lankisch, P. G., Arnold, R., and Creutzfeldt, W. (1975). Wirkung von Somatostatin auf die betazol-stimulierte Magensekretion und die Carbachol-stimulierte Pankreassekretion und Gallenblasenkontraktion des Menschen. Deutsche Medizinische Wochenschrift, 100, 1797-1800.

Luft, R., Efendic, S., Hökfelt, T., Johansson, O., and Arimura, A. (1974). Immunohistochemical evidence for the localization of somatostatin-like immunoreactivity in a cell population of the pancreatic islets. Medical Biology, 52, 428-430.

Mortimer, C. H., Tunbridge, W. M. G., Carr, D., Yeomans, L., Lind, T., Coy, D. H., Bloom, S. R., Kastin, A., Mallinson, C. N., Besser, G. M., Schally, A. V., and Hall, R. (1974). Effects of growth-hormone release-inhibiting hormone on circulating glucagon, insulin, and growth hormone in normal, diabetic, acromegalic, and hypopituitary patients. Lancet, 1, 697-701.

Polak, J. M., Pearse, A. G. E., Grimelius, L., Bloom, S. R., and Arimura, A. (1975). Growth-hormone releaseinhibiting hormone in gastro-intestinal and pancreatic D cells. Lancet, 1, 1220-1222.

Ricketts, H. T. (1975). Somatostatin, hormone inhibitor. Journal of the American Medical Association, 231, 391-392.

Russell, R. C. G., Bloom, S. R., Fielding, L. P., and Bryant, M. G. (1976). Current problems in the measurement of gastrin release. A reproducible measure of physiological gastrin release. Postgraduate Medical Journal, 52, 645-650.

Vatier, J., Cheret, A. M., and Bonfils,'S. (1968). Le dosage automatique de l'activité protéolytique du suc gastrique. Biologie et Gastroenterologie (Paris), 1, 15-29.

Wincey, C., and Marks, V. (1961). A micro-method for measuring glucose using the Autoanalyser and glucoseoxidase. Journal of Clinical Pathology, 14, 558-559 